\title{
人造鉱物について
}

\author{
Synthetic Minerals
}

犬 塚 英 夫* (Eiłeo Inuzuka)
今 井环 也**(Takuya Imai)

1. 緒

雫

自然產の鉱物を人工的に製造しよ.万とする試みは随分古くからの念願であ つた。ことに寶石と呼ばれるダイアモンド, コランダム, 綠挂石等老製造し そいと願うことは，金を卑金属から鍊金しょうとするのと同じである。ガラ

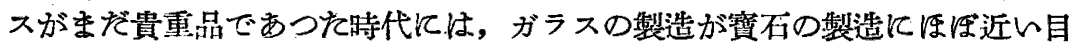
的であつたということがでをよう。この事実は紀元前のエジプト・アッシリ ヤに源を発し, Monro'), Neumanr.2) 両氏その他の研究も西るが, かれわれ はガランと人造鉱物とは一応分離して考えたい。

鉱物をつくる目的は第一に有用鉱物の量產にあり，第二に生成条件の垖求 そあるが，その端緒付 19世紀末の Moissan の時代に始り, 現在ダイアモン ド・コランダム・スピネル・緑杜不・ルチル等の䁚石の他に, 圧電気材料と しての水晶電気絕縁材料の雲耿, 電僻用隔膜としての石緔, 理化学用の食塩 加里岩塩, 螢石, チリ㗂石その他が試作され，をだ応用部門は明らかではな レが各種無石の人工的製造も進められている。これらの概略は本部で野田氏 の総說3).があり，最近の海外報交をる Greer ${ }^{4)}$, Zerfass ${ }^{5)}$, Baner \& Ke-

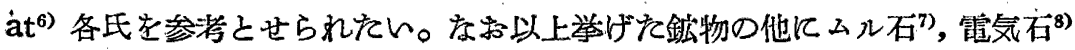
沸石 ${ }^{9}$, 水晶石 ${ }^{10)}$ 等の製造成功が伝えられている。

このような人造鉱物は結晶として利用されるこてが多く，必然的に単一大 型結晶を要求される。本稿で讨蜜業原料のような絬晶の聚合体沉は言及しな レことにする。

さて，人造鉱物の製法で西るが，結晶の生長は大別して水の存在する場合 之存在しない場合があり, 後者はさらに水蒸気存在下で生長するるの, 高压 熱水存在下で生長するるの，常圧水溶液中で生長するるのとに区別出来る。 これらの人造鉱物の代表として比较㳔近年長足の進步をとげた水晶及びコラ

東京芝浦霞気株式会往, マツダ研究所, 㸴究部第七課長

** 日本電與林式会往, 技衔部, 東京的究室主任 

この破碎片は種水晶 (F) が次第に大きくなるにつれ ( $\mathrm{H}$ ) の溶体の本衡 が破れ, $\mathrm{SiO}_{2}$ 分が不足する場合の補充原料である。種水晶（F）は純粹疗8 ので包有物を含ます，一定方向のるのでなければならない。したがつて草入 水晶・着色水晶・双晶のようなものは好ましくない。種はワイヤーで內管上 部に近くつりさげ, 炭酸ナトリウム $\left(\mathrm{N} \approx{ }_{2} \mathrm{CC}_{3}\right)$ 又は水酸化ナトリウム $(\mathrm{Na}$ $\mathrm{OH}$ ) 飽和液を室溫で內管の約 $89 \%$ 程度むで満たすのである。—この丁ル カリ液恃 $\mathrm{Na}_{2} \mathrm{CO}_{3}$ と $\mathrm{NaOH}$ と並用することるあり, Nacken 氏は重炭酸 ナトリウムを使用したが目的はい执る同一である。—これらの準備が完 了すれば內管は各接続部を熔接しこの為に凹部を有する保持カップ (C) が 必要となつてくる。溫度が上昇するにしたがい內管內は压力が增大し膨脹の

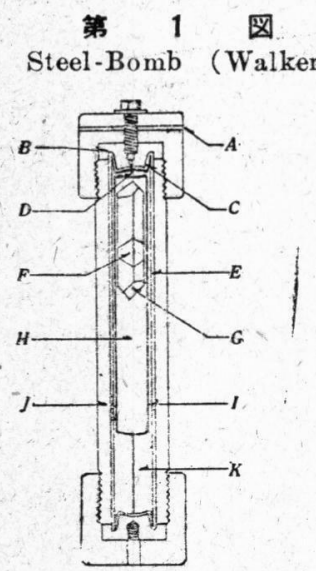
A : Vent
B : Welded rim
C : Tapered cup
D : Safety diaphram
E : Liner
F : Seed
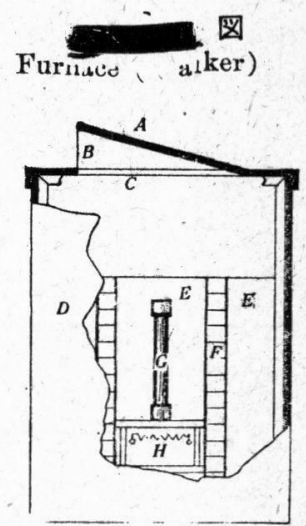

A : Sheet metal cover

B : Vent

C : Screen

$\mathrm{D}:$ Sheet metal cover

E : Mica insulation

F : Insulating fire brick

G : Bomb,

$\mathrm{H}$ : Electric heating

結果外壁に密着する形となりこれれは直接高熱アルカリが外部のステンレス 鋼と反応するのを防ぐに有效で, 総体として 20,000 psi 亿耐える耐圧容器を 使用せねばをらない。—-(H) とおいて压は約 15,000 psi 亿上昇し外管の 上部溫度は約 $380^{\circ} \mathrm{C}$, 下部は約 $400^{\circ} \mathrm{C}$ 飞保をれる。すを沈ち, この耐圧封管 は第 2 図に示す师に裝置し（E）を約 $425^{\circ} \sim 450^{\circ} \mathrm{C}$ 亿加熱し，数週間にかた つて放置されるのである。このような方法で種水晶が段々に大きく生長する 
過程は主に次のどとを経過によると考えられる。これらの反応の詳しい経過 は Franke 氏の報文20)がある。

（i ）破碎水晶（K）江溫度・圧力の增加と共に融解し次第に（H）のアル カリは $\mathrm{SiO}_{2}$ 飽和に近つく。

（ii）文流が生じて移動する $\mathrm{S}: \mathrm{O}_{2}$ 飽和液悑充原料 $(\mathrm{K})$ とアルカリ腹 $(\mathrm{H})$ との界面におんて丁度飽和とたり，実際には內管上部は下部より約 10〜 $20^{\circ} \mathrm{C}$ 低溫であるので種水晶のつられた部分において $\mathrm{SiO}_{2}$ は過飽和となつ てくる。

（iii）過飽和になつた $\mathrm{SiO}_{2}$ は徐々に種水晶（F）に附着し，水晶の生長が 開始される。

（iv）種水晶に一部の $\mathrm{SiO}_{2}$ を附着させ再び飽和に杘つたアルカリは対流に よつて下部に送られ新しく飽和にたつて杘つてくる。

（v）このような生長過程は內管下部の補充原料が溶けて上述の条件を満足 させる間継続し,補充原料部に生するる減圧部（原料が消耗して生する空陌） は種水晶の生長を促進するのに役立つ。

（vi） 水晶の生長は均一でなく，生長量壮 $\mathrm{R}$ カツトとZカットで约 1:5の 重量比を示す14)。大体以上の方法で3?日間放置した人造水晶は徑 3 インチ

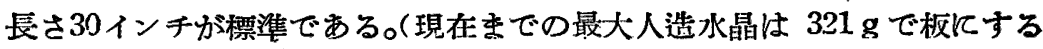
と $2{ }^{3 / 4} \times 1^{1 / 2} \times{ }^{3 / 1} / 1$ インチのものである ${ }^{12) 。 ~}$

以上で人造水晶の製法を主に紹介の立場から概說したが，何分このような裝 置は根本的に改革されない限り 1 日侐か 0.025 インチ程度の生長度急激に 改める事俚困難と恩われる。勿論裝置を大沉し压力・時間・溫度を変化させ ることで現在より大型の人造水晶をより短時日で製造するのは吅能であろう が今のところ画期的方方法はをだ発表されておらないようである。

\section{3. コランダム}

人造コランダム (synthetc corundum) は一般に色調いかんに拘らずサ ファイアと㭔ばれてレ゙るが,天然髉のコランダムと同じくアルミナ $\left(\mathrm{Al}_{2} \mathrm{O}_{3}\right)$ を 主成分とし若干の着色剂を加えて製造する。したがつてその硬度・比重・䢃 開面・属折率等は性とんど天然產のそれらと類似し, 製造技術の進步と共に 仲飞制别注困難になつてきている。人造寶石の分野は 1880年 Hanney ${ }^{21)}$ 氏 の試作に始つたダイアモンドの他に種ふの寶石が作られているが，1895年に Michand 氏がルビーを試作し，1902年にVerneuil 炉が製作され全く新し ん方法でコランダムが作られるようになつて長足の隻步をとげてきたのです 
る。勿論当初の製品は透明が著しく見劣りし也調輝度の点でる到底天然產に 立向うことはできなかつねが, 時計の軸石に大量使用されるに至り急激にル ビーの需要は增加した。しかも一頃の人造コランダムの最大の販路が印度で ありこの人造品が天然品とませて逆輸出されていたとは実に皮肉な事実であ Dた。

本邦においても昭和10年前後より日本カーバイド・日窒・東芝の各社で試 作研究が開始され主として計器類の軸受石が製造されそが, 戦争の宾陌によ り現在はいづれる東芝技術の流れをくむ信光社・日本電興の二㣖のみが製品 を市場に供給している実情である。

炏にその製造方法であるが，近時急速に進步をなし，数年の間に我ねが見 出しえた特許も Nortun $\mathrm{Co}^{23)}$ Linde Air Yroducts Co. ${ }^{24)}$, Benaix Aviation Corp., ${ }^{25)}$ Carbidwerk Spoerry ${ }^{26)}$, Carbor-

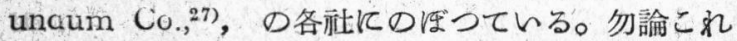
らの中には製造方法のみを出願したものでなく碵質 原料としてのコランダム (Aiundum) 製造に主力 を置いたものもあるがこの他にもスイスには Swiss Jewel Co., Hrand Djèvahirdjian Co., 等Ф 有力会社があり，ソ連・ドイッ・チエツコスロバキ ヤ・オーストラリア・フランスの各国でも相当研究 が進められているものと思う。

普通採用されている方法愉 3 図に示すヴェルヌ イ炉を使用しコランダムを製造するのであるがおお よそ次の経過をねどつて行われる。

\section{(契 法)}

第 3 図はヴェルヌイの裝置である。水㿟と異り直 接原料を上部より落下せしめ，これを酸水素バーナ 一で熔解して下部に結晶を生長せしめる。（A）はア ルミナを主成分とする原料入で包りその下部は細い 笠（B）になつていて, 上部の槌で衡撃を受けると 均一に落下するようになつている。原料アルミナは 酸素の送大之共に ( $\mathrm{G})$ のアルミナ質保持台の上に 落下するが, 途中で水素が送入せられ灿內溫度は少 くとも $2050^{\circ} \mathrm{C}$ 以上に上昇しているから実際には蓩 狀になつて落下し徐ふに結晶は生長を開始する。し

第 3 図

Vern euil apparatus

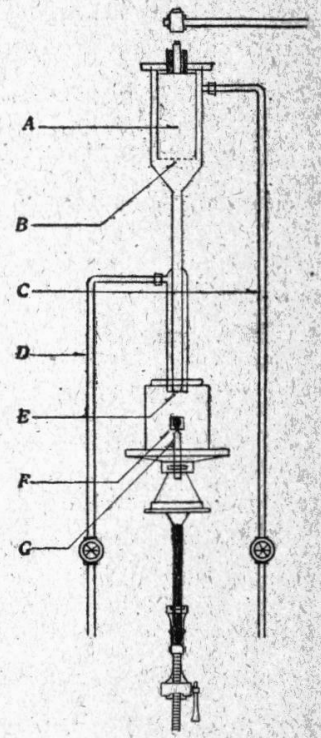

A : Receptacle

B : Fine sieve

C : $\mathrm{O}_{2}-$ gas

$\mathrm{D}: \mathrm{H}_{2}$-gas

E : Fire

F : Boule

G : Support. 
そがつて保持台を加減し酸水素量を增減することによつてある程度任意のコ ランダム結晶を得ることが可能である。一般にこのようなコランダム結晶は Boule と呼ばれ我ねは約 2,000 カラットの原石を試作したこともあるが，こ の条件を勘案すると 200 ～400 カラットのものが一 番使用し易く，製造 る容 易であると考える。

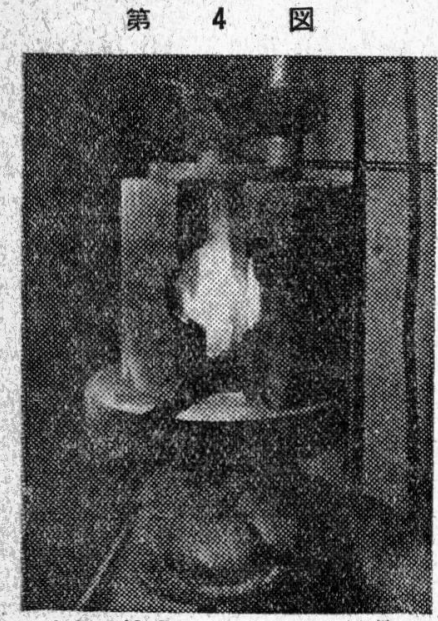

酸水素焰中でコランダム結晶の 作られるところ
第 5 図

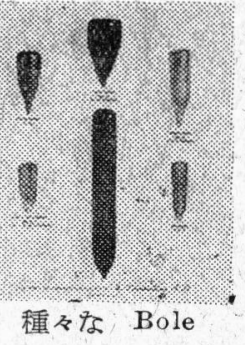

\section{(原料)}

実際の製品とL ての良否は勿論そ の製造方法に或 る程度左右される が，現在のように 殆んど各社共同一 の方法で生產して いる狀況では原料 の選択が製品に影響する点も見逃せない であろう。その主原料はいらまでもなく アルミナ $\left(\mathrm{Al}_{2} \mathrm{O}_{3}\right)$ であり, アルミナに 対する研究恃兒に多くのものが報告され ている28)-41)。アルミナは元来いるいろ な変態を有し $\alpha \cdot \beta \cdot \gamma \cdot \delta \cdot \zeta \cdot \theta \cdot \kappa$ の各アルミナが知られているが,この 中には相当疑問とされるべき点が散在し，ま落フアイア原料としてのアル ミナ研究は系統的にはなされておらない。今井・小林42)がアルミナ原料たる アンモニウム・アラム $\left[\left(\mathrm{NH}_{4}\right)_{2} \mathrm{SO}_{4} \mathrm{Al}_{2}\left(\mathrm{SO}_{4}\right)_{3} \cdot 24 \mathrm{H}_{2} \mathrm{O}\right]$.を加熱しつ〉アル ミナえ燒成される減量曲線を求め, 各燒成物の Debye-Scherrer 法によるX 線粉末写真を比較したところ，950〜 $1300^{\circ} \mathrm{C}$ の間においては本質的な変化を

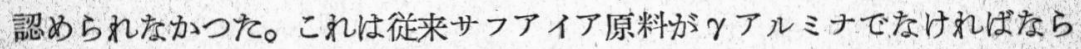

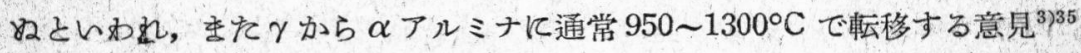
〜 年) そ相容いたい。しかし我及は直接 $\alpha$ アルミナよりサフアイアを製造でき

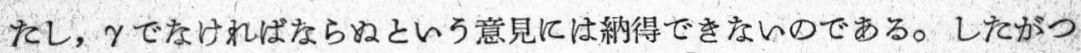
てアラムの燒成過程で直接 $\alpha$ アルミナが生成されたという予想も成立するが むしろ極めて純粹孛 $\gamma$ アミナにおいて性鉱化を促進して $\alpha$ アルミナとす る条件が充分には満足出来なかつたのではをいかと考える。実際に着色䎟 $\mathrm{Cr}_{2} \mathrm{O}_{3}$ 考添加したアルミナは $1250^{\circ} \mathrm{C}$ 附近に抬いて黄加ら桃色に変化し著し 


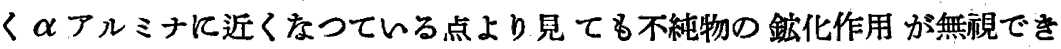
ないことを示している。この鉱化作用についての研究壮主としてスピネルに 対する野口氏の報文 ${ }^{43}$ がある。

次にアルミナ中の不純成分であるが，多田・今井の分光分析を主体とした 分析結果 ${ }^{44)}$ では $-\mathrm{H}_{2} \mathrm{O}$, 灼熱減量, $\mathrm{SO}_{3}$ の他飞 $\mathrm{SiO}_{2}, \mathrm{Fe}_{2} \mathrm{O}_{3}, \mathrm{CaO}, \mathrm{MgO}$ $\mathrm{Na}_{2} \mathrm{O}, \mathrm{K}_{2} \mathrm{O}, \mathrm{TiO}_{2}, \mathrm{Cr}_{2} \mathrm{O}_{3}$ がありさらに最近では $\mathrm{CuO}, \mathrm{PbO}, \mathrm{Ag}_{2} \mathrm{O}$, $\mathrm{Ga}_{2} \mathrm{O}_{3}$ 等を検出した。これらの不純物壮極めて微量でありその影響を研究す ることはすこぶる難しいが, 相当量混在しても妨害とならねるのもあり, 逆 に極めて微量混在しても妨害之なるものもあつて一樣に結論づけることはで きぬであろう。しかしながら天然物の分析結果 ${ }^{45) 4(6) 47)}$ は $\mathrm{SiO}_{2}, \mathrm{Fe}_{2} \mathrm{O}_{2}, \mathrm{CaO}$, $\mathrm{MgO}$, 等を相当量含み, このような不純物につんての考察は Pevzner 氏48) その他の報文 ${ }^{4950) 51)}$ がある。これらの不純物は笔・気泡・硬度低下・色調 不均一等の不良原因になる一方, 直接寶石としての価值を左右する原石の着 色倣となることがあるので軽をしく諭ずることは差控えたい。

要するに我々の経験からんつて原料としての要訛はできるだけ次の諸条件 を満足でをるアルミナが望ましいわけである。

(i) 化学的に純粹であること

(ii) “燒むら”のないこと

(iii）粒子が均一でかつ蓠比重の小であること

(iv）着色剤が均一にまじり得るようなアルミナですること。その他。

\section{（渵色剂）}

原料アルミナは純粹な $\mathrm{Al}_{2} \mathrm{O}_{3}$ であるが近時わざわざ不純物を添加してサ

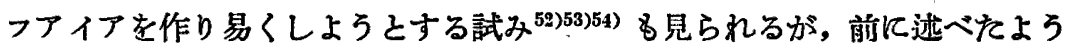
に不純物の種類と量によつて当然得られるサフアィアの色は盾々の制限を受

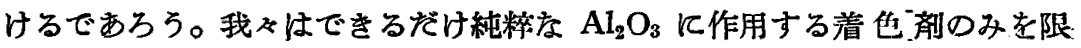
定しその種類をここに述べることとする。

Rnby：寶石として人造コランダムの中王座を占めるものは依然としてル ビーである。この製造は Frè ny ${ }^{55)}$ 氏が唧に 19世紀末より開始し天然產でる $\mathrm{Cr}_{9} \mathrm{O}_{2}$ を0.10〜 1.25\%含有することがあると Dapish 氏は述べているのであ るが，むしろこの場合は $\mathrm{Cr}_{2} \mathrm{O}_{3}$ よりも $\mathrm{Fe}_{2} \mathrm{O}_{3}$ の方が着色郕として優位に立 つている。しかしながら現在ルビー着色郕として $\mathrm{Cr}_{2} \mathrm{O}_{3}$ を添加するのは既に 常識となり $\mathrm{Cr}_{2} \mathrm{O}_{3}$ を添加するかしないかが閏題になるのではなく、んかなる 形で, レかなる量までの $\mathrm{Cr}_{2} \mathrm{O}_{3}$ の添加が可能であるかというここに研究の 
主眼が置かれているのである。即ち従来 $2.5 \%$ が $\mathrm{Cr}_{2} \mathrm{O}_{3}$ の添加限度であつた

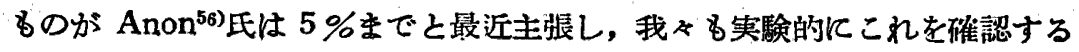
ことができた。 $\mathrm{Cr}_{2} \mathrm{O}_{3}$ が添加量によつて赫ら緑に変化するが, この結晶学 的考考察は Thiio 氏等が報告している

Sapphire : 一般飞 $\mathrm{F}_{2} \mathrm{O}$ を添加して青色を是せしめるがこれは磁器の釉と 同様である。ただし多量に混合すると“色むら”のできることるあつてある 程度以上の添加はいたがらに FeO の揮散量を增加せしめる結果となる。極 めて微量の $\mathrm{TiO}_{2}$ 添加が青出の促進風となるといわれている。

Emerald : 正確には emerald-like の green corundum そ呼ぶべきで あろう。需要量は少いがアメリカにおいて最も歓迎される寶石の一つです る。したがつて各㼛共その詳しい製造法恃公開していたい。一般にはVとCo あるいは磁鉄鉱 $\left(\mathrm{Fe}_{3} \mathrm{O}_{4}\right)$, あるいは $\mathrm{Ni}$ と $\mathrm{Fe}$ 等といかれているが濁りのな い紓色を得ることは至難である。天然のエメラルドは綠㤬石 $\left(3 \mathrm{BeO} \cdot \mathrm{A}_{2} \mathrm{O}_{3}\right.$ ・ $\left.6 \mathrm{SiO}_{2}\right)$ の一種で少量の $\mathrm{Cr}_{2} \mathrm{O}_{3}(0.2 \%$ 程度) を含む椊綠色の寶石をいう。

Alexandri'e : これも正確に性 alexandrite-like の orun'um 乙呼ぶへ きであろう。天然のるのは $\mathrm{BeO} \cdot \mathrm{Al}_{2} \mathrm{O}_{3}$ の組成に近い金綠石の一種であるが 特に反射光線は綠で透過光線で紶色のものをアレキサンドライトと呼ぶので ある。しかし一般には $\mathrm{V}_{2} \mathrm{O}_{5}$ 老的 $3 \%$ 程度アルミナに混合し,アレキサンド ライトと呼ぶ人造寶石を製造している。このようにしばしば天然產と人造物 とでは呈色元素を異にすることがある。

その他：上記の他に $\mathrm{NiO}, \mathrm{TiO}_{2}, \mathrm{CoO}$, 等孝着色偊として添加し, ある いは上記の着色剤の混合率を変化させて yellow-sapphire, rose-sapphire, violet-sap Spinel 等の類似寶石の製造も仃能である。

スピネル $\left(\mathrm{MgO} ・ \mathrm{Al}_{2} \mathrm{O}_{3}\right)$ の製造方法はこの項に直接関係はないけれどる 全くサフアイアの場合と同㥞にして製造される。ただしこの際の主原料は $\mathrm{Al}_{2} \mathrm{O}_{3}+\mathrm{MgO}$ であり着色郕恃多少異る。ルチル rutile $\left(\mathrm{TiO}_{2}\right)$ 同樣を裝 置で製造が可能で, アメリカでは裝飾用として既に販売されている。本邦に おいて陚作が進み間もなく市場にでることであろう。ルチルの場合は原料が チタン白 $\left(\mathrm{TiO}_{2}\right)$ で酸水素バーナーの加減が困難であるのでサフフイア程大 きなボールは出来ていないが, 原料の純度によつては天然產のものより潘か に美しいるのが得られる。

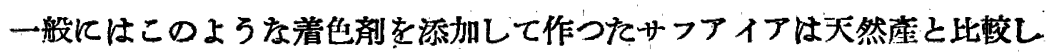


て見た時, 屈折率は恬とんど変らず, $\left(\omega \mathrm{Na}=1.7680 \sim 1.7715, \varepsilon_{\mathrm{Nu}}=1.7594\right.$ $1.7632, \omega-\varepsilon=0.0080 \sim 0.0086)$ 比重恃多少 (3.96 4.03) となつている ${ }^{58)}$ 。 結晶構造上の変化その他はまだ刵つてない面すあるのでここには割愛する。

\section{(用途)}

これら人造コランダムが大量に生產されるにしたがいその用途も単価の低 減に準じて堽加した。従来裝身其用としてのみ若えられた寶石類も次第にそ の特性が利用せられ始めたといつてもよいであろう。これらについては広瀨 氏その他の人ネが紹介の学をとられている59がその例を少しばかり挙げてみ る。

\section{( i ) 裝身具}

最近生活の安定と共にサフアイア本来の用途である裝身具用寶石の需要が 漸增する傾向にある。比較的安価で床質的に天然產コランダムと変りのない ルビー・アレキサンドライト・サフアイア・スピネル等が歓迎されるのも当 然であるが，まだ天然産と判别不能な原石製造までには至つていないのは残 念なことである。すなわち天然產と同一の組成を持ち原石を同じようにカッ トしてもどことなくいかゆる briiliancy において劣つている。これは將来 結晶学上の立場から解决されるべをであり， star ruby, star sapphire の 製造と共に興味ある䦗題である。

(ii ) 時計用軸受石

時計に使用されている石は瓜とんど人造コランダムであるといつて過言で

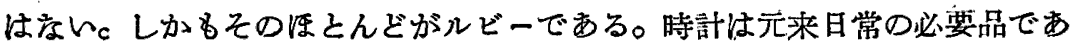
ると共に裝飾用の意味を持ち，軸受石としても小型であるから濃出のものが 歓迎され一ケ月に約35万カラット以上の原不が使用されている。

(iii) 電気機器用掸受石

電気計器用のサフアイアは時計と違つて裝飾用の意味は全然ない。したが つて安価で硬度の大であるホワイト・サフアイアが主として用いられるかけ である。その主な用途は積算電力計用で一ケ月に約 30 万カラット程度使用さ れる。他に電気計器といえをいかも知れねが船舶の羅針儀・鉄道の自仍信号 機等にもサフアイアは使用されているのである。

(iv) レコード针

レコードの長時間酎用針は従来金属針が用いられていたが磨擦音が少く， 同時に硬度が高くて磨耗が少いのでサフアイア針が次第に普及して来た。し かし硬度の大であることは逆に micro-groove 甥め易しことにもなるから 
この加エは仲々困難である。

錄音用の針はこれと異り従来もダイアモンド針が探用せられていた位であ るから多少硬度は小であろらと安価の点でサフアィア針は大んに歓脑せられ ている。このような針の硬度壮当然サフアイアの結晶軸仗支配され東大の伊 藤貞市・森博両氏が研究を進めている。

(v) その他

サフアイアは硬度と共に酎酸・耐アルカリの点で優秀であり表面の磨擦係 数が小であるからその slim rod を化学繊維工芘用の guide として, ある いは nozz.e として使用されればすこぶる有然である。スリム・ロツドは酸 水素熖で加工が可能であるが我々の実験でけ刍裂面が残存し易く今のところ これを防止すること壮不矿能である。

サフアイアの特性として第二に举げられる点はガラスに比し屈折率が大で 分散值が小であること及び雨熱性のあることである。これは光学レンズとし ての用涂, 耐熱性の透過空としての利用が考えられる。我ふは直徑約 1.3 イ ンチの円板を試作し得をからその応用を今後考えたん。

\section{4. 結 語}

以上簡単に人造鉱物製造の現況を紹介した。思うに人造鉣物の將来は谷ふ 進展の徴があり，ここにはその一例として水晶とコランダムのみを挙げたけ れぞも，工業の進步と共に要求される人造鉣物の種類乙量仗次第に增してい くであろち。一般に人造鉱物は多くの労力と時間を必要とするものであり， またその加工工程も細心さを姴する部門が多いから，本邦において極めて有 望を事業である。ただ我くの遺憾とすることはこれらの設備は莫大な資金を 要し, その予供実験乃至理論的れ基礎研究もまた容易でをんことである。ス イスが世界一の時計国となつた一面には人造サフアイアの試作に最も熱心で あり，その加工技術が優秀であつた点を忘れてはをるまい。しかもその牙城 は莫大太资本と撓まざる研究に依つてアネッカその他の国々に侵玲されつつ ある実情である。

最後に文献調查及び貴重を示唆を頂いた諸氏に御礼申上げる。

\section{文}

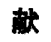

1) W: L. Monro : Window glass making, 21 (1926)

2) B. Neumann : Z. angew. chem, 8, 203 (1928)

3) 野田稳吉 : 化工 $3[5], 124$ (1950) 

